\title{
Neurotransmitters in the Mammalian Striatum: Neuronal Circuits and Heterogeneity
}

\author{
K. Semba, H.C. Fibiger and S.R. Vincent
}

\begin{abstract}
The major input and output pathways of the mammalian striatum have been well established. Recent studies have identified a number of neurotransmitters used by these pathways as well as by striatal interneurons, and have begun to unravel their synaptic connections. The major output neurons have been identified as medium spiny neurons which contain $\gamma$-aminobutyric acid (GABA), endogeneous opioids, and substance P. These neurons project to the pallidum and substantia nigra in a topographic and probably chemically organized manner. The major striatal afferents from the cerebral cortex, thalamus, and substantia nigra terminate, at least in part, on these striatal projection neurons. Striatal interneurons contain acetylcholine, GABA, and somatostatin plus neuropeptide Y, and appear to synapse on striatal projection neurons. In recent years, much activity has been directed to the neurochemical and hodological heterogeneities which occur at a macroscopic level in the striatum. This has led to the concept of a patch-matrix organization in the striatum.
\end{abstract}

RÉSUMÉ: Les neurotransmetteurs dans le striatum des mammifères: circuits neuronaux et hétérogénéité. Les principales voies afférentes et efférentes du striatum chez les mammifères ont été bien établies. Des études récentes ont identifié certains neurotransmetteurs utilisés par ces voies ainsi que par les interneurones du striatum et ont commencé à préciser leurs connexions synaptiques. Les principaux neurones efférentes ont été identifiés comme étant les neurones épineux de taille moyenne qui contiennent de l'acide $\gamma$-aminobutyrique (GABA), des opioïdes endogènes et de la substance $P$. Ces neurones ont des projections, organisées topographiquement et probablement chimiquement, vers le pallidum et la substance noire. Les principaux neurones afférents depuis le cortex cérébral, le thalamus et la substance noire se terminent, du moins en partie, sur ces neurones de projection du corps strié. Les interneurones du corps strié contiennent de l'acétylcholine, du GABA et de la somatostatine et du neuropeptide Y, et semblent faire synapse avec les neurones de projection du corps strié. Ces dernières années, plusieurs études ont porté sur l'hétérogénéité neurochimique et hodologique qui se rencontre au niveau macroscopique dans le striatum. Ces recherches ont mené à l'élaboration du concept de l'organisation du striatum en matrice parcellaire.

Can. J. Neurol. Sci. 1987; 14:386-394

The striatum contains a variety of neurotransmitters, some of which have been associated with neurological disorders including Parkinson's and Huntington's diseases. The purpose of the present review is to provide an updated, brief summary of the recent advances in our knowledge of the biochemical anatomy of the striatum, with particular emphasis on: 1) the synaptic connections among striatal afferents, projection neurons, and interneurons, and 2) the neurochemical and hodological heterogeneities in the striatum. The reader is referred to the following reviews for more comprehensive treatment of the literature on the anatomy and neurochemistry of the striatum. ${ }^{1-6}$

\section{Striatal InPUTS}

The cortical afferents

The major striatal input arises in the cerebral cortex which projects topographically to the striatum. At a gross level, the putamen receives primarily sensorimotor information, while the caudate nucleus receives major inputs from the limbic and associational cortical areas. The corticostriatal input has been suggested to arise from both supragranular and infragranular cortical layers, and some corticostriatal cells may also project to other subcortical regions. ${ }^{7-9}$ Although most of the corticostriatal 
projection arises from the ipsilateral cortex, as much as a third of the cortical projections to the striatum arises in the opposite hemisphere. ${ }^{10}$ The corticostriatal afferents terminate principally in asymmetric contacts on the spines of the medium spiny striatal neurons. ${ }^{11.12}$ There is much circumstantial evidence to suggest that the corticostriatal fibers use an excitatory amino acid, perhaps glutamate, as a transmitter. ${ }^{13}$

\section{The thalamic afferents}

The second major striatal input arises in the thalamus. Although the major sources are the intralaminar nuclei, some striatal afferents also arise in "specific" thalamic nuclei including the ventral anterior, ventral lateral, lateral posterior and suprageniculate nuclei. ${ }^{14,15}$ As with the corticostriatal projection, the thalamostriatal pathway is topographically organized. ${ }^{16}$ Some of the thalamostriatal fibers send collaterals to the cerebral cortex ${ }^{14}$ Again, like the cortical afferents, terminals arising from thalamic neurons appear to form primarily asymmetric contacts with the dendritic spines of the medium spiny neurons. ${ }^{3}$

Although the thalamostriatal projection appears to be excitatory, ${ }^{3.17}$ the transmitters contained in this pathway are not known. There was a suggestion that this pathway is cholinergic, ${ }^{18}$ but this does not appear to be the case. ${ }^{19}$ Some neuropeptides have recently been detected in thalamostriatal neurons. Cells in the centromedian-parafascicular complex in the cat projecting to the caudate nucleus have been shown to contain substance P-, vasoactive intestinal polypeptide (VIP)-, cholecystokinin (CCK)- and neurotensin-immunoreactivities. ${ }^{20.21}$ Some of the enkephalin in the cat striatum could also arise in the intralaminar thalamus where met-enkephalin-immunoreactive cell bodies are present. ${ }^{22}$

\section{The nigral afferents}

The well known nigrostriatal dopaminergic projection provides a third major input to the striatum. In addition, a small non-dopaminergic projection from the substantia nigra also appears to exist. ${ }^{23-26}$ As with the other striatal afferents, the nigrostriatal projection is topographically organized (e.g., ${ }^{26}$ ). The dopaminergic terminals tend to form symmetric contacts with dendrites and with the stalks of dendritic spines. ${ }^{27.28}$ Many of these spines also receive asymmetric inputs, probably arising in the cortex and thalamus. ${ }^{27.28}$ Thus dopaminergic terminals may be well placed to modulate the actions of other inputs on the striatal neurons.

Some nigrostriatal dopaminergic neurons also contain neuropeptides. CCK-immunoreactivity is found in many of the ventral tegmental dopamine neurons projecting to ventral striatal regions including the nucleus accumbens and olfactory tubercle..$^{29.30}$ Neurotensin may also be present in some of these neurons. ${ }^{31.32}$

\section{Other inputs}

The striatum receives numerous other projections. While a serotonin afferent from the dorsal raphe has been well documented ${ }^{33}$ many of the afferents from the raphe area are dopaminergic. ${ }^{34}$ Histaminergic neurons in the posterior hypothalamus project to many areas including the striatum. ${ }^{35} \mathrm{~A}$ pallidostriatal projection has been recently discovered, ${ }^{36,37,37 \mathrm{a}}$ as has an input from the subthalamic nucleus. ${ }^{38} \mathrm{~A}$ fairly large input from the amygdala has been noted. ${ }^{39-41} \mathrm{CCK}$ immunoreactivity may be present in striatal afferents originating in the basolateral amygdala, claustrum and piriform cortex. ${ }^{30.42}$ Other minor projections from brainstem areas such as the locus ceruleus (noradrenergic) and the pedunculopontine nucleus (cholinergic) require further confirmation. ${ }^{37 a .43}$

\section{Striatal Outputs}

Evidence from biochemical experiments following various lesions has indicated that there is a population of $\gamma$-aminobutyric acid (GABA) neurons in the striatum. ${ }^{44-46}$ These studies also indicate that striatal GABA neurons project to the pallidum and substantia nigra. The development of antibodies to the GABA synthesizing enzyme, glutamate decarboxylase (GAD), has permitted the morphological analysis of striatal GABA neurons. Bolam et $\mathrm{al}^{47,49}$ have found that neurons which accumulate $\left[{ }^{3} \mathrm{H}\right] \mathrm{GABA}$ or display GAD immunoreactivity are not medium spiny neurons. Rather, these cells have the morphological features of a type of medium aspiny cell. This morphology is similar to those of GAD-positive cells seen previously by Ribak et $\mathrm{al}^{50,51}$ in the rat striatum, and by Panula $\mathrm{et}^{\mathrm{l}} \mathrm{l}^{52}$ in cultures of rat striatum. Bolam et al ${ }^{47,49}$ suggest that these cells might be striatal GABA interneurons, and that the striatonigral GABA projection neurons may not be labelled by the GABA uptake technique, possibly because of insufficient local axon collaterals. Similarly, the striatonigral GABA neurons may not be readily detected with GAD antisera if most of their GAD is rapidly transported out of the striatum to the pallidum and nigra. Recent studies using a different antiserum have demonstrated GAD immunoreactivity in two populations of rat striatal neurons, a small population of medium to large neurons which was detected in normal animals, and a larger population of medium-sized neurons that was detected after colchicine treatment. ${ }^{53}$ In the cat, GAD immunoreactivity has been demonstrated in retrogradely labelled medium-sized spiny striatonigral neurons. ${ }^{54}$ These cells received symmetric GAD-immunoreactive axosomatic and axodendritic contacts, plus many asymmetric nonimmunoreactive contacts on their soma, dendrites and spines. ${ }^{54}$

Medium-spiny striatonigral neurons have also been labelled with tritiated taurine. ${ }^{55}$ This raises the possibility that taurine and GABA might coexist in some of these cells. In addition, many of the medium-spiny striatal projection neurons displaying GAD immunoreactivity have been found to contain leu- or met-enkephalin. ${ }^{53,56-60}$ Hökfelt et $\mathrm{al}^{61}$ first described the presence of enkephalin-immunoreactive neurons in the rat striatum. These cells appear to project massively upon the globus pallidus. ${ }^{62}$ Enkephalin-immunoreactive neurons have also been observed in the cat ${ }^{60,63}$ and primate striatum. ${ }^{64.65}$

Pickel et $\mathrm{a}{ }^{66}$ have found that medium spiny neurons in the rat striatum contain enkephalin-immunoreactivity. Kubota et al ${ }^{67}$ detected axosomatic symmetrical tyrosine hydroxylase (TH)immunoreactive contacts on enkephalin-immunoreactive medium spiny neurons. Striatal enkephalin terminals form symmetric contacts with dendrites of medium spiny neurons that also receive asymmetric contacts from cortical afferents. ${ }^{68.70}$ Somogyi et $\mathrm{al}^{69}$ reported that leu-enkephalin-immunoreactive terminals also form symmetric contacts with neurons similar to the rare aspiny striatonigral neuron described by this group. ${ }^{72}$ In addition these investigators reported the presence of a few asymmetric axospinous contacts made by leu-enkephalin-immunoreactive boutons. Axoaxonic contacts between cortical afferents and enkephalin terminals may also occur in the rat striatum. ${ }^{70}$ 
In the cat, about half of the medium-sized spiny enkephalinimmunoreactive neurons contain neurotensin immunoreactivity, and half the neurotensin-immunoreactive neurons display enkephalinimmunoreactivity. ${ }^{63}$ Dynorphin-immunoreactive neurons have been detected in the rat striatum, ${ }^{73}$ and these also appear to project to the substantia nigra. ${ }^{74}$

Substance P-immunoreactive neurons are also found in the striatum. ${ }^{75-78}$ In fact, substance $P$ coexists in many GAD- and enkephalin-immunoreactive neurons in the rat and cat striatum. ${ }^{60}$ In an ultrastructural study of the rat striatum, Bolam et a ${ }^{48}$ identified two types of substance P-immunoreactive neurons. One appears to correspond to the medium spiny neuron, while the other appears to be an aspiny medium-sized neuron, probably distinct from the aspiny GABA or somatostatin neurons. ${ }^{48}$ Substance P-immunoreactive boutons appear to form symmetric synaptic contacts usually on dendrites or spines of what are perhaps medium spiny neurons. ${ }^{48}$ The morphology of these contacts is similar to that of substance P terminals in the substantia nigra, and may thus derive from collaterals of striatonigral substance $P$ neurons. ${ }^{71,79}$

Although substance $P$, enkephalin and dynorphin are found in medium spiny neurons together with GAD, the extent to which these substances coexist in the striatal efferents is not known. Dense terminal staining for enkephalin is present in the external segment of the globus pallidus, while for substance $\mathbf{P}$ the densest terminal fields are present in the internal pallidal segment and substantia nigra. ${ }^{78,80,81}$ These observations suggest a chemical coding of the striatal GABA efferents, with those projecting to the globus pallidus containing predominantly enkephalin, and those projecting to the entopeduncular nucleus and substantia nigra containing mainly substance $P$.

\section{Striatal Interneurons}

It is clear from numerous immunohistochemical studies in various species that the cholinergic neurons of the striatum correspond to the large aspiny neurons described in Golgi studies. This was originally proposed by Lehmann et al ${ }^{82}$ on the basis of pharmacohistochemical studies of acetylcholinesterase $(\mathrm{AChE})$. Kimura et $\mathrm{al}^{83}$ subsequently demonstrated that the large striatal cells in the rat and guinea pig did in fact display choline acetyltransferase (ChAT) immunoreactivity. This has since been confirmed in various species including rat ${ }^{84} \mathrm{cat}^{85.86}$ and primate. ${ }^{87}$ The ultrastructure of these neurons has been examined in the rat using both AChE histochemistry ${ }^{88,88 a}$ and ChAT immunohistochemistry ${ }^{89,90}$ Although often referred to as the large or giant aspiny neuron, the soma and dendrites of this cell type are often sparsely spiny. These neurons receive rare symmetric axosomatic and axodendritic contacts, ${ }^{88-90}$ plus some asymmetric contacts. ${ }^{89,90}$ In addition, the axonal initial segments of these neurons appear to receive symmetric synapses..$^{90}$ Bolam et $\mathrm{al}^{91}$ have recently demonstrated that the cell bodies and proximal dendrites of striatal cholinergic neurons in the rat receive symmetrical contacts from substance P-immunoreactive boutons. The cholinergic terminals make symmetric contacts with somata, dendrites and axon initial segments of what appear to be medium spiny neurons. ${ }^{90,92}$

In addition to the giant aspiny cholinergic neurons, other smaller aspiny interneurons are present in the striatum. Light and electron microscopic immunohistochemical studies have indicated that somatostatin is contained in one such popu- lation. ${ }^{93-95}$ Another peptide, neuropeptide Y (NPY) is present in the striatal somatostatin neurons, ${ }^{95,96}$ which are also characterized by the presence of NADPH-diaphorase activity. ${ }^{97.98}$ These striatal neurons receive only a few symmetric and asymmetric inputs to their soma and proximal dendrites, ${ }^{99-101}$ while the distal dendrites usually have asymmetric contacts. ${ }^{99.100}$ Somatostatin-immunoreactive boutons form symmetrical contacts with dendrites and spines. ${ }^{99.100}$ The spines receiving somatostatin-immunoreactive input also receive other asymmetrical contacts. ${ }^{100}$

Although other neuropeptides have been noted in striatal neurons, these have not been analysed in detail. CCK-immunoreactivity is found in a small population of medium aspiny neurons. ${ }^{102} \mathrm{~A}$ few neurons containing VIP $\mathrm{P}^{103}$ and galanin ${ }^{104}$ may also be present.

Although important questions regarding the organization of the striatum remain, it may be helpful to summarize our current knowledge of the basic striatal circuit as follows: the major functional unit of the striatum appears to be the medium spiny neuron. These cells receive the major inputs from cortex, thalamus and substantia nigra, and supply the major output to the pallidum and substantia nigra. The cholinergic, GABAergic, and somatostatin/NPY-containing interneurons could thus act to modulate the activity of the medium spiny neurons. Major questions that are still unanswered include: 1) Do the striatal interneurons receive cortical, thalamic or nigral input to their distal dendrites? 2) Do all medium spiny neurons receive similar inputs? 3) What are the connections of the aspiny striatonigral neurons, and the aspiny GABA interneurons? 4) How is this striatal circuitry accommodated in the plan of the regional heterogeneity that is now becoming apparent in the striatum (see below)?

\section{Heterogeneity in the Striatum}

Studies over the past decade have revealed that the striatum displays considerable heterogeneity with respect to cytoarchitecture ${ }^{105-107}$ and, in particular, the distribution of various neurotransmitter-related markers, and afferent and efferent connections. In addition to regional differences, there is a mosaic pattern in which the presence or absence of a given anatomical marker is localized to "patches" against the background or "matrix". Moreover, the "patches" revealed by different markers do not appear to be independent from each other, but display varying degrees of correspondence. These observations have led to the suggestion that this mosaic pattern may represent the basic organizational plan of compartmentalization in the mammalian striatum.

As intriguing as the concept is, there are limitations in the current data that suggest a striatal patch-matrix organization. The concept is at present based entirely on qualitative observations. The patch and matrix compartments have been commonly defined by either opiate receptor binding, neuropeptide immunoreactivity, or AChE staining, and increasingly these are being assumed to demarcate identical regions. Until these matches are firmly established in quantitative terms, the results of the studies using different markers to define the patch and matrix compartments may not be directly comparable. The observations reviewed below should be considered with these caveats in mind. 


\section{Neurochemistry}

Early reports on macroscopic heterogeneity in the striatum were made with AChE staining in cat, monkey, and human, ${ }^{108}$ and opiate receptor binding with $\left[{ }^{3} \mathrm{H}\right]$-diprenorphine in the rat. ${ }^{109}$ AChE histochemistry reveals occasional zones, about $0.5 \mathrm{~mm}$ in width, of pale staining. These AChE-poor zones, termed "striosomes", were subsequently reported to match the "islands" of opiate receptors revealed by $\left[{ }^{3} \mathrm{H}\right]$-naloxone binding in the rat striatum, 110 as well as the compartments of high met-enkephalin-like ${ }^{11,113}$ and dynorphin-B-like immunoreactivity in the dorsal striatum of cats and kittens. ${ }^{113}$

Neurotensin-positive neuropil also appears to be in register with enkephalin-like immunoreactive neuropil and AChE-poor zones in the cat. ${ }^{1 / 4}$ This is consistent with the coexistence of these two peptides. ${ }^{63}$ However, unlike opiates and opiate receptors, the distributions of neurotensin and its receptors do not appear to be coincident; high densities of neurotensin receptors are found in the opiate-poor, AChE-rich matrix. ${ }^{115}$

Substance $P$ immunoreactive neuropil is largely confined to AChE-poor striosomes in rat ${ }^{116}$ and cat. ${ }^{11,113}$ Substance P-positive perikarya are seen more frequently in the patches, defined by dense substance $P$ neuropil, than in the matrix in rat, ${ }^{60}$ baboon, and human striatum. ${ }^{78}$

Somatostatin immunoreactive fibers have been reported to be dense in the matrix defined by the absence of opiate receptor binding, substance $P$ or enkephalin immunostaining in rat ${ }^{116,117}$ and cat. ${ }^{94,111}$ The distribution of NPY is heterogeneous, with patchy zones of weak immunoreactivity in the cat, whereas it is homogeneous in the monkey. ${ }^{6}$ Dense NADPH-diaphorase staining appears to be in register with the AChE-rich matrix in the cat. ${ }^{118}$ Somatostatin-immunoreactive cell bodies are found in both patches and matrix in the rat, although their processes are seen mostly in the matrix. ${ }^{116,117}$

The distribution of cholinergic neurons has been reported to be homogeneous. ${ }^{119}$ More recently, using an antiserum to ChAT combined with $\mathrm{AChE}$ staining in cat and monkey, Graybiel et al $^{120}$ have reported that ChAT-positive neuropil is confined to AChE-rich matrix zones. Concentrations of muscarinic receptors revealed by $\left[{ }^{3} \mathrm{H}\right]$-propylbenzilylcholine mustard in the cat appear to correspond to $\mathrm{AChE}$-poor patches in the dorsal striatum. ${ }^{121}$ However, a homogeneous density was seen with $\left[{ }^{3} \mathrm{H}\right]$-quinuclidinyl benzilate. ${ }^{122}$

Neither dopamine fluorescence nor $\mathrm{TH}$ immunoreactivity displays obvious heterogeneity in adult animals, ${ }^{123,124}$ although they form "islands" in immature animals (see below). A heterogeneity has been reported to be detected in adult animals by quantitative analyses of TH immunohistochemistry. ${ }^{125}$ The patchy pattern of TH immunoreactivity can also be "unmasked" in adult rats by pretreatment with a $\mathrm{TH}$ inhibitor. ${ }^{126.127}$ In the human striatum, the density of $\mathrm{D} 2$ receptors is high in AChErich matrix regions. ${ }^{128}$

\section{Connections}

The mosaic patterns seen with various neurochemical markers described above have been reported to be superimposed, to a considerable extent, on the terminal patterns of various afferents and the distributions of projection neurons. Heterogeneous patterns of terminations described as "patchy" were noted in autoradiographic studies of corticostriatal ${ }^{107,129}$ and thalamostriatal projections. ${ }^{15.130}$ Recently, Donoghue and Herkenham ${ }^{131}$ have shown in adult rats that prelimbic frontal cortical afferents tend to terminate in opiate receptor dense patches, and the afferents from the somatosensory, visual, motor, and cingulate cortices terminate in the matrix. The termination of the afferents from the medial prefrontal (or prelimbic) cortex in the patches defined by the absence of somatostatin neuropil has also been reported in the rat. ${ }^{116}$ In adult cat and monkey, Ragsdale and Graybiel ${ }^{132}$ have reported that in the dorsal half of the caudate nucleus, the presence of afferent terminals from the frontal cortex matches with AChE-poor striosomes, whereas in the ventral half, the absence of afferent terminals tends to be in register with the striosomes. Varicose terminals of afferents from the parafascicular thalamic nucleus are found to distribute heterogeneously in the cat, ${ }^{133}$ outside of opiate receptor dense islands, and within the AChE-rich matrix in the rat. ${ }^{110}$ Amygdalostriatal projections have been reported to terminate in patchy patterns in the monkey. ${ }^{4}$

The nigral afferents also appear to have a heterogeneous distribution of terminal labelling in the striatum of the rat ${ }^{134}$ and cat. ${ }^{133}$ The projection from the ventral tegmental area has been reported to terminate predominantly in the matrix of the ventral striatum, including the nucleus accumbens, in the rat. ${ }^{135}$ More recently in a systematic study of the projection to the striatum from the ventral tegmental area (A10), substantia nigra (A9), and retrorubral area $(A 8)$, Gerfen et $\mathrm{al}^{26}$ have reported that dopaminergic fibers from the ventral part of the substantia nigra pars compacta and the ventral tier of the pars reticulata (displaced A9 cells) terminate in the opiate receptor-dense patches, whereas both dopaminergic and non-dopaminergic afferents from all the other areas terminate outside of the patches. In addition, those dopaminergic neurons giving rise to the afferents to the matrix, but not those innervating the patches, contain a calcium binding protein, and appear to develop later than those without this protein. ${ }^{136}$

A mosaic pattern is also seen in efferent projections of the striatum. Graybiel et al ${ }^{137}$ have reported that projection neurons (mostly medium-sized) retrogradely labelled following HRP injections into the globus pallidus and substantia nigra are found largely in the AChE-rich matrix compartment in the cat. In the rat, Gerfen ${ }^{117}$ has reported that striatal neurons projecting to the substantia nigra pars compacta are located in somatostatin-poor patches, whereas those projecting to the pars reticulata are located in the matrix.

The above findings suggest that the striatum may be segregated in a mosaic manner into two compartments which represent two separate input-output channels. The patch compartment receives a major input from the prelimbic cortex and its output is directed to the substantia nigra pars compacta. The matrix compartment receives major afferents from the sensory and motor cortices and the centromedian-parafascicular complex of the thalamus, and directs its output to the substantia nigra pars reticulata.

\section{Development}

The heterogeneity of some striatal neurochemical markers develops during embryonic development and is already present at birth. These include enkephalin neuropil in the cat, ${ }^{111}$ and opiate receptor binding, ${ }^{124.138,139}$ muscarinic receptors, ${ }^{140}$ neurotensin, and neurotensin receptors ${ }^{141}$ in the rat. However, there are also markers whose distributions change during development. For example, AChE staining reveals dense patches, rather than pale patches as seen in adults, in the striatum of 
neonatal rats, ${ }^{142}$ fetal and neonatal cats, ${ }^{111.112}$ and human fetus and young infants. ${ }^{143}$ Dopamine fluorescence, which is homogeneous in adult rats, begins to display heterogeneity on embryonic day 19; this develops into conspicuous "islands" by the time of birth, but then gradually fades by postnatal day $16 .{ }^{123.124}$ Lança et al ${ }^{139}$ have shown that the ratio of the opiate receptordense patches to the total striatal area peaks on postnatal day 7 .

In neonatal and fetal cats, the AChE-rich patches correspond to dopamine islands, ${ }^{12}$ as well as to the patches of enkephalin-, and, to some extent, substance P-positive neuropil. ${ }^{111}$ Matching of dopamine islands and dense AChE staining is not surprising because most of the $\mathrm{AChE}$ seen early during development is probably contained within dopaminergic fibers from the substantia nigra. ${ }^{144}$ It is, however, not clear how the reversal of the AChE staining pattern occurs during development.

In the cat, using $\left[{ }^{3} \mathrm{H}\right]$-thymidine autoradiography, Graybiel and Hickey ${ }^{145}$ have shown that neurons which became postmitotic around embryonic day 24 to 30 (the gestation period of the cat is 65-68 days) tend to form clusters which were superimposed on AChE-poor striosomes and enkephalin-rich compartments. On the basis of $\left[{ }^{3} \mathrm{H}\right]$-thymidine-dense patches as a marker, Nastuk and Graybiel ${ }^{121}$ suggested that the AChE-dense patches seen in neonatal cats are the precursor of the AChE-poor striosomes seen in adults. In the rat, van der Kooy and Fishell ${ }^{146}$ have reported that neurons which become postmitotic earliest (embryonic day 13-15) are located in the patches defined by opiate receptor binding, whereas those cells leaving the mitotic cycle later (embryonic day 18-20) are found in the matrix. Similar observations have been made by Marchand and Lajoie. ${ }^{147}$ Although the mechanisms of the formation of patch-matrix compartments are unknown, Lança et al ${ }^{139}$ suggested that the striatal connections with the brainstem are important in the formation and/or maintenance of the matrix-patch compartments (see also ${ }^{148}$ ).

\section{CONCLuSIONS}

The mammalian striatum, particularly its dorsal part, appears to be segregated into two neurochemically and hodologically separate compartments: patches and matrix. The two compartments are organized in a mosaic pattern in which the patch compartment forms a labyrinth through the matrix compartment, giving the appearance of Swiss cheese. Although the functions of the two compartments need to be examined by physiological techniques, this mosaic structure raises the possibility of parallel information processing through two anatomically segregated input-output channels. Similar compartmentalization of functionally related neurons has been seen in ocular dominance columns $^{149}$ and vibrissal barrels ${ }^{150}$ in the cerebral cortex.

Historically, the concept of the patch-matrix organization began with a few early independent observations of macroscopic heterogeneity in histochemical staining and connections. These initial observations have been extended, with the aid of more recently developed anatomical tools, and integrated into a novel concept of striatal organization. The underlying hypothesis which has stimulated all these studies has been that the striatal heterogeneities reflect anatomically and functionally segregated compartments. As previously stated, the hypothesis has so far been based entirely on qualitative observations, and there is a need to determine the degree of matching in quantitative terms. Quantitative tests should include an exami- nation of the extent of matching among different neurochemical/ hodological labelling conducted on the same or alternate sections. Such examinations would provide a foundation on which studies using different markers to define the patch and matrix compartments become mutually comparable, and also may indicate the "best" marker to use in future studies.

Attention also should be paid to the fact that the mosaic pattern may not be evident in all regions of the striatum. Heimer and Wilson ${ }^{151}$ have proposed that the striatum consists of two subregions: the dorsal, non-limbic part, and the ventral, limbic part. At present it appears that the most conspicuous patches as well as the most consistent matching between different markers occur in the dorsal striatum. In the ventral striatum, patches are less obvious and the matching is either less convincing, absent, or sometimes, reversed. One explanation for such regional differences is that some peptides are contained in afferents which terminate heterogeneously in the striatum. ${ }^{117}$

Although the segregation of patches and matrix in the dorsal striatum seems relatively convincing at the macroscopic level, the information at the cellular level remains limited to some preliminary data with projection neurons and somatostatincontaining interneurons. Gerfen ${ }^{116}$ has noted that striatal neurons retrogradely labelled with fluorescent tracers have dendrites mostly confined to the somatostatin-dense compartment containing their cell bodies. Consistent results have been reported for medium spiny neurons in an abstract by Penny et al ${ }^{152}$ using the intracellular HRP technique, which can reveal more extensive dendritic fields than retrograde labelling.

The issue of somatostatin-containing neurons as link neurons which connect the patch and the matrix compartments requires further clarification. Gerfen ${ }^{116.117}$ has reported that, although somatostatin-immunoreactive cell bodies are found in both matrix and patches, axons of these neurons in patches extend into surrounding matrix in rat. This has led Gerfen ${ }^{16.117}$ to suggest that somatostatin-containing neurons may play a role as a link from the patches to the matrix. Similar observations have been made in the cat. ${ }^{94}$ However, these authors considered it unlikely that a major function of somatostatin neurons is linking, because cross-compartmental somatostatin fibers do not occur frequently. The question of possible link neurons, as well as the dendritic morphology of striatal neurons, in general, in relation to the patch-matrix organization might be better addressed by combining intracellular injection techniques with immunohistochemistry.

\section{ACKNOWLEDGEMENTS}

Supported by grants from the Medical Research Council of Canada, and the British Columbia Health Care Research Foundation.

\section{REFERENCES}

1. Carpenter MB. Anatomy of the corpus striatum and brain stem integrating systems. In: Handbook of Physiology. Sect. 1 The Nervous System, Vol. II. Motor Control, Part 2, Brookhart JM, Mountcastle VB, Brooks VB, eds. American Physiological Society, Washington, DC, 1981: 947-995.

2. Graybiel AM, Ragsdale CW Jr. Biochemical anatomy of the striatum. In: Chemical Neuroanatomy, Emson PC, ed. Raven Press, New York, 1983: 427-504.

3. Groves PM. A theory of the functional organization of the neostriatum and the neostriatal control of voluntary movement. Brain Res Rev 1983; 5: 109-132. 
4. Bolam JP. Synapses of identified neurons in the neostriatum. In: Functions of the basal ganglia (Ciba Foundation Symposium 107), Pitman, London, 1984: 30-47.

5. McGeer EG, Staines WA, McGeer PL. Neurotransmitters in the basal ganglia. Can J Neurol Sci 1984; $11: 89-99$.

6. Parent A. Comparative neurobiology of the basal ganglia. Wiley, New York, 1986.

7. Kitai ST, Kocsis JD, Wood J. Origin and characteristics of the cortico-caudate afferents: An anatomical and electrophysiological study. Brain Res 1976; 118: 137-141.

8. Jones EG, Coulter JD, Burton H, et al. Cells of origin and terminal distribution of corticostriatal fibers arising in the sensory-motor cortex of monkeys. J Comp Neurol 1977; 173: 53-80.

9. Royce GJ. Laminar origin of cortical neurons which project upon the caudate nucleus: A horseradish peroxidase investigation in the cat. J Comp Neurol 1982; 205: 8-29.

10. Fisher RS, Shiota C, Levine MS, et al. Interhemispheric organization of corticocaudate projections in the cat: A retrograde doublelabelling study. Neurosci Lett 1984; 48: 369-373.

11. Kemp JM, Powell TPS. The site of termination of afferent fibers in the caudate nucleus. Phil Trans Roy Soc, London, 1971: 262: 413-427.

12. Somogyi P, Bolam JP, Smith AD. Monosynaptic cortical input and local axon collaterals of identified striatonigral neurons. A light and electron microscopic study using the Golgi-peroxidase transport-degeneration procedure. J Comp Neurol 1981; 195: 567-584.

13. Fonnum F, Storm-Mathisen J, Divac I. Biochemical evidence for glutamate as neurotransmitter in corticostriatal and corticothalamic fibers in rat brain. Neurosci $1981 ; 6: 863-873$.

14. Jones EG, Leavitt RY. Retrograde axonal transport and the demonstration of non-specific projections to the cerebral cortex and striatum from thalamic intralaminar nuclei in the rat, cat and monkey. J Comp Neurol 1974; 154: 349-378.

15. Royce GJ. Autoradiographic evidence for a discontinuous projection to the caudate nucleus from the centromedian nucleus in the cat. Brain Res 1978; 146: 145-150.

16. Beckstead RM. The thalamostriatal projection in the cat. J Comp Neurol 1984; 223: 313-346.

17. Kitai ST. Electrophysiology of the corpus striatum and brain stem integrating systems. In: Handbook of Physiology, Sect. 1. The Nervous System, Vol II. Motor control, Part 2, Brookhart JM, Mountcastle VB, Brooks VB, eds. American Physiological Society, Washington, D.C., 1981: 997-1015

18. Saelens JK, Edwards-Neale S, Simke JP. Further evidence for cholinergic thalamo-striatal neurons. J Neurochem 1979; 32; 1093-1094.

19. Fibiger $\mathrm{HC}$. The organization and some projections of cholinergic neurons of the mammalian forebrain. Brain Res Rev 1982; 4: 327-388.

20. Sugimoto T, Takada M, Kaneko T, et al. Substance P-positive thalamocaudate neurons in the center median-parafascicular complex in the cat. Brain Res 1984; 323: 181-184.

21. Sugimoto T, ltoh K Yasui Y, et al. Coexistence of neuropeptides in projection neurons of the thalamus in the cat. Brain Res 1985 347: $381-384$

22. Covenas R, Romo R, Cheramy A, et al. Immunocytochemical study of enkephalin-like cell bodies in the thalamus of the cat. Brain Res 1986; 377: 355-361.

23. Fibiger HC, Pudritz RE, McGeer PL, et al. Axonal transport in nigro-striatal and nigro-thalamic neurons: Effects of medial forebrain bundle lesions and 6-hydroxydopamine. J Neurochem 1972; 19: 1697-1708.

24. Guyenet PG, Crane JK. Non-dopaminergic nigrostriatal pathway. Brain Res 1981:213: 291-305.

25. Van der Kooy D, Coscina DV, Hattori T. Is there a non-dopaminergic nigrostriatal pathway? Neurosci 1981; 6: 345-357.

26. Gerfen $C R$, Herkenham $M$, Thibault J. The neostriatal mosaic: II. Compartmental organization of mesotriatal dopaminergic and non-dopaminergic systems. J Neurosci (In press).

27. Bouyer JJ, Park DK, Joh TH, et al. Chemical and structural analysis of the relation between cortical inputs and tyrosine hydroxylase-containing terminals in rat neostriatum. Brain Res $1984 ; 302: 267-275$
28. Freund TF, Powell JF, Smith AD. Tyrosine hydroxylase-immunoreactive boutons in synaptic contacts with identified striatonigral neurons, with particular reference to dendritic spines. Neurosci 1984; 13: 1189-1216.

29. Hökfelt T, Skirboll L, Rehfeld JF, et al. A subpopulation of mesencephalic dopamine neurons projecting to limbic areas contains a cholecystokinin-like peptide: Evidence from immunohistochemistry combined with retrograde tracing. Neurosci 1980 5: 2093-2124

30. Zaborszky L, Alheid AF, Beinfeld MC, et al. Cholecystokinin innervation of the ventral striatum: A morphological and radioimmunological study. Neurosci 1985; 14: 427-453.

31. Hökfelt T, Everitt BJ, Theodorsson-Norheim E, et al. Occurrence of neurotensin-like immunoreactivity in subpopulations of hypothalamic, mesencephalic, and medullary catecholamine neurons. J Comp Neurol 1984: 222: 543-559.

32. Kalivas PW, Miller JS. Nerotensin neurons in the ventral tegmental area project to the medial nucleus accumbens. Brain Res 1984; 300: 157-160.

33. Parent A, Descarries L, and Beaudet A. Organization of ascending serotonin systems in the adult rat brain. A radioautographic study after intraventricular administration of $\left[{ }^{3} \mathrm{H}\right] 5$-hydroxytryptamine. Neurosci 1981: 6: 115-138.

34. Descarries L, Berthelet F, Garcia S, et al. Dopaminergic projection from nucleus raphe dorsalis to neostriatum in the rat. $\mathbf{J}$ Comp Neurol 1986; 249: 511-520.

35. Steinbusch HWM, Sauren Y, Groenewegen HJ, et al. Histaminergic projections from the premammillary and posterior hypothalamic region to the caudate-putamen complex in the rat. Brain Res 1986; 368: 389-393.

36. Staines WA, Atmadja S, Fibiger HC. Demonstration of a pallidostriatal pathway by retrograde transport of HRP-labelled lectin. Brain Res 1981; 206: 446-450.

37. Beckstead RM. A pallidostriatal projection in the cat and monkey. Brain Res Bull 1983a; 11: 629-632.

37a. Parent A, Mackey A, De Bellefeuille L. The subcortical afferents to caudate nucleus and putamen in primate: A fluorescenece retrograde double labelling study. Neuroscience, 1983; 10: 1137-1150.

38. Beckstead RM. A reciprocal axonal connection between the subthalamic nucleus and the neostriatum in the cat. Brain Res 1983b; 275: 137-142.

39. Kelly AE, Domesick VB, Nauta WJH. The amygdalostriatal projection in the rat: An anatomical study by anterograde and retrograde tracing method. Neurosci 1982; 7: 615-630.

40. Fass B, Talbot K, Butcher LL. Evidence that efferents from the basolateral amygdala innervate the dorsolateral neostriatum in rats. Neurosci Lett 1984; 44: 71-75.

41. Russchen FT, Bakst I, Amaral DG, et al. The amygdalostriatal projections in the monkey. An anterograde tracing study. Brain Res 1985; 329: 241-257.

42. Meyer DK, Beinfeld MC, Oertel WH, et al. Origin of the cholecystokinin-containing fibers in the rat caudatoputamen. Science 1982; 215: 187-188.

43. Saper CB, Loewy AD. Projections of the pedunculopontine tegmental nucleus in the rat: Evidence for additional extrapyramidal circuitry. Brain Res 1982: 252: 367-372.

44. Kim JS, Bak IJ, Hassler R, et al. Role of $\gamma$-aminobutyric acid (GABA) in the extrapyramidal motor system. 2. Some evidence for the existence of a type of GABA-rich strionigral neuron. Exp Brain Res 1971; 14: 95-104.

45. Fibiger HC. Organization of GABA-containing neurons in some extrapyramidal nuclei. J Can Neurol Sci 1980; 7: 251:252.

46. Staines WA, Nagy JI, Vincent SR, et al. Neurotransmitters contained in the efferents of the striatum. Brain Res 1980; 194: 391-402.

47. Bolam JP, Clarke DH, Smith AD, et al. A type of aspiny neuron in the rat neostriatum accumlates $\left[{ }^{3} \mathrm{H}\right]-\gamma$-aminobutyric acid: combination of Golgi-staining, autoradiography and electron microscopy. J Comp Neurol 1983; 213: 121-134.

48. Bolam JP, Somogyi $\mathrm{P}$, Takagi $\mathrm{H}$, et al. Localization of substance $P$-like immunoreactivity in neurons and nerve terminals in the neostriatum of the rat: A correlated light and electron microscopic study. J Neurocytol 1983; 12: 325-344. 
49. Bolam JP, Powell JF, Wu J-Y, et al. Glutamate decarboxylaseimmunoreactive structures in the rat neostriatum: A correlated light and electron microscopic study including a combination of Golgi impregnation with immunocytochemistry. J Comp Neurol 1985; $237: 1-20$

50. Ribak CE, Vaughn JE, Roberts E. The GABA neurons and their axon terminals in rat corpus striatum as demonstrated by GAD immunocytochemistry. J Comp Neurol 1979; 187: 261-284.

51. Ribak CE. The GABAergic neurons of the extrapyramidal system as revealed by immunocytochemistry. In: GABA and the basal ganglia, ed. Di Chiara G, Gessa GL. Raven Press, New York 1981, 187: 261:284.

52. Panula $P, W u J-Y$, Emson $P$. Ultrastructure of GABA-neurons in cultures of rat neostriatum. Brain Res 1981; 219: 202-207.

53. Oertel WH, Mugnaini E. Immunocytochemical studies of GABAergic neurons in rat basal ganglia and their relations to other neuronal systems. Neurosci Lett 1984; 47: 233-238.

54. Fisher RS, Buchwald NA, Hull CD, et al. The GABAergic striatonigral neurons of the cat: demonstration by double peroxidase labeling. Brain Res 1986; 398: 148-156.

55. Clarke DJ, Smith AD, Bolam JP. Uptake of $\left[{ }^{3} \mathrm{H}\right]$ taurine into medium-size neurons and into identified striatonigral neurons in the rat neostriatum. Brain Res 1983; 289: 342-348.

56. Aronin N, Difiglia M, Graveland GA, et al. Localization of immunoreactive enkephalins in GABA synthesizing neurons of the rat neostriatum. Brain Res 1984; 300: 376-380.

57. Morelli M, Di Chiara G. Coexistence of GABA and enkephalin striatal neurons and possible coupling of GABA-ergic and opiatergic systems in the basal ganglia. Neuropharm 1984; $23: 847$.

58. Zahm DS, Zaborszky L, Alones VE, et al. Evidence for the coexistence of glutamate decarboxylase and met-enkephalin immunoreactivities in axon terminals of rat ventral pallidum. Brain Res 1985; 325: 317-321.

59. Aronin N, Chase K, Difiglia M. Glutamic acid decarboxylase and enkephalin immunoreactive axon terminals in the rat neostriatum synapse with striatonigral neurons. Brain Res 1986;365: 151-158.

60. Penny GR, Afsharpour S, Kitai ST. The glutamate decarboxylase-, leucine enkephalin-, methionine enkephalin-and substance P-immunoreactive neurons in the neostriatum of the rat and cat: evidence for partial population overlap. Neurosci 1986; 17 : 1011-1045.

61. Hökfelt T, Elde R, Johansson O, et al. The distribution of enkephalinimmunoreactive cell bodies in the rat central nervous system. Neurosci Lett 1977; 5: 25-31.

62. Cuello AC, Paxinos G. Evidence for a long leu-enkephalin striopallidal pathway in rat brain. Nature $1978 ; 271$ : 178-180

63. Sugimoto $T$, Mizuno N. Immunohistochemical demonstration of neurotensin in striatal neurons of the cat, with particular reference to coexistence with enkephalin. Brain Res 1986; 398: 195-198.

64. Haber S, Elde R. The distribution of enkephalin immunoreactive neuronal cell bodies in the monkey brain: Preliminary observations. Neurosci Lett 1982; 32: 247-252.

65. Inagaki S, Parent A. Distribution of enkephalin-immunoreactive neurons in the forebrain and upper brainstem of the squirrel monkey. Brain Res 1985; 359: 267-280.

66. Pickel VM, Sumal KK, Beckley SC, et al. Immunocytochemical localization of enkephalin in the neostriatum of rat brain: A light and electron microscopic study. J Comp Neurol 1980; 189: 721-740.

67. Kubota $Y$, Inagaki S, Kito $S$, et al. Ultrastructural evidence of dopaminergic input to enkephalinergic neurons in rat neostriatum. Brain Res 1986; 367: 374-378.

68. Difiglia M, Aronin N, Martin JB. Light and electron microscopic localization of immunoreactive leu-enkephalin in the monkey basal ganglia. J Neurosci 1982; 2: 303-320.

69. Somogyi P, Priestly JV, Cuello AC, et al. Synaptic connections of enkephalin-immunoreactive nerve terminals in the neostriatum: A correlated light and electron microscopic study. J Neurocytol 1982b; 11: 779-807.

70. Bouyer JJ, Miller RJ, Pickel VM. Ultrastructural relation between cortical afferents and terminals containing enkephalin-like immunoreactivity in the rat neostriatum. Regulat Pep 1984a; 8: 105-115.

71. Somogyi P, Priestley JV, Cuello AC, et al. Synaptic connections of substance P-immunoreactive nerve terminals in the substantia nigra of the rat: A correlated light- and electron- microscopic study. Cell Tissue Res 1982a; 223: 469-486.
72. Bolam JP, Somogyi P, Totterdell $S$, et al. A second type of striatonigral neurons: A comparison between light and electron microscopic levels. Neurosci 1981; 6: 2141-2157.

73. Vincent SR, Hökfelt T, Christensson 1, et al. Dynorphinimmunoreactive neurons in the central nervous system of the rat. Neurosci Lett 1982a; 33: 185-190.

74. Vincent SR, Hökfelt T, Christensson 1 , et al. Immunohistochemical evidence for a dynorphin immunoreactive striato-nigral pathway. Europ J Pharmacol 1982b; 85: 251-252.

75. Kanazawa I, Emson PC, Cuello AC. Evidence for the existence of substance P-containing fibres in striato-nigral and pallidonigral pathways in rat brain. Brain Res 1977; 119: 447-453.

76. Cuello AC, Kanazawa 1. The distribution of substance P immunoreactive fibers in the rat central nervous system. J Comp Neurol 1978; 178: 129-156.

77. Ljungdahl A, Hökfelt T, Nilsson G. Distribution of substance P-like immunoreactivity in the central nervous system of the rat - I. Cell bodies and nerve terminals. Neurosci 1978; 3: 861-943.

78. Beach TG, McGeer EG. The distribution of substance $P$ in the primate basal ganglia: An Immunohistochemical study of baboon and human brain. Neurosci 1984; 13: 29-52.

79. Difiglia M, Aronin N, Leeman SE. Immunoreactive substance P in the substantia nigra of the monkey: light and electron microscopic localization. Brain Res 1981; 233: 381-388.

80. Haber S, Elde R. Correlation between met-enkephalin and substance $\mathrm{P}$ immunoreactivity in the primate globus pallidus. Neurosci 1981; 6: 1291-1298.

81. Haber SN, Nauta WJH. Ramifications of the globus pallidus in the rat as indicated by pattems of immunohistochemistry. Neurosci 1983; 9: 245-260.

82. Lehmann J, Fibiger HC. Acetylcholinesterase and the cholinergic neurons. Life Sci 1979; 25: 1939-1947.

83. Kimura $\mathrm{H}, \mathrm{McGeer} \mathrm{PL}$, Peng F, et al. Choline acetyltransferasecontaining neurons in rodent brain demonstrated by immunohistochemistry. Science 1980; 208: 1057-1069.

84. Satoh K, Armstrong DM, Fibiger HC. A comparison of the distribution of central cholinergic neurons as demonstrated by acetylcholinesterase pharmacohistochemistry and choline acetyltrans. ferase immunohistochemistry. Brain Res Bull 1983a; 11:693-720.

85. Kimura H, McGeer PL, Peng JH, et al. The central cholinergic system studied by choline acetyltransferase immunohistochemistry in the cat. J Comp Neurol 1981; 200: 151-201.

86. Vincent SR, Reiner PB. The immunohistochemical localization of choline acetyltransferase in the cat brain. Brain Res Bull 1987; 18: 371-415.

87. Satoh K, Fibiger HC. Distribution of central cholinergic neurons in the baboon (Papio papio). I. General morphology. J Comp Neurol 1985; 236: 197-214.

88. Satoh K, Staines WA, Atmadja S, et al. Ultrastructural observations of the cholinergic neuron in the rat striatum as identified by acetylcholinesterase pharmacohistochemistry. Neurosci 1983b; 10: $1121-1136$.

88a. Bolam JP, Ingham CA, Smith AD. The section-Golgi-impregnation procedure - 3. Combination of Golgi-impregnation with enzyme histochemistry and electron microscopy to characterize acetylcholinesterase-containing neurons in the rat neostriatum. Neurosci $1984 ; 12 ; 687-709$

89. Bolam JP, Wainer BH, Smith AD. Characterization of cholinergic neurons in the rat neostriatum. A combination of choline acetyltransferase immunocytochemistry. Golgi-impregnation and electron microscopy. Neurosci 1984; 12: 711-718.

90. Phelps PE, Houser CR, Vaughn JE. Immuncytochemical localization of choline acetyltransferase within the rat neostriatum: A correlated light and electron microscopic study cholinergic neurons and synapses. J Comp Neurol 1985; 238: 286-307.

91. Bolam JP, Ingham CA, Izzo PN, et al. Substance P-containing terminals in synaptic contact with cholinergic neurons in the neostriatum and basal forebrain: A double immunocytochemical study in the rat. Brain Res 1986; 397: 279-289.

92. Wainer BH, Bolam JP, Freund TF, et al. Cholinergic synapses in the rat brain: A correlated light and electron microscopic immunohistochemical study employing a monoclonal antibody against choline acetyltransferase. Brain Res 1984; 308: 69-76.

93. Finley JCW, Grossman GH, Dimeo P, et al. Somatostatin-containing neurons in the rat brain: Widespread distribution revealed by 
immunocytochemistry after pretreatment with pronase. Am J Anat 1978; 153: 483-488.

94. Chesselet MF, Graybiel AM. Striatal neurons expressing somatostatin-like immunoreactivity: Evidence for peptidergic interneuronal system in the cat. Neurosci 1986; 17: 547-571.

95. Smith Y, Parent A. Neuropeptide Y-immunoreactive neurons in the striatum of cat and monkey: Morphological characteristics, intrinsic organization and co-localization with somatostatin. Brain Res 1986; 372: 241-252.

96. Vincent SR, Skirboll L, Hökfelt T, et al. Coexistence of somatostatinand avian pancreatic polypeptide (APP)-like immunoreactivity in some forebrain neurons. Neurosci 1982c; 7: 439-446.

97. Vincent SR, Johansson O, Hökfelt T, et al. NADPH-diaphorase: A selective histochemical marker for striatal neurons containing both somatostatin- and avian pancreatic polypeptide (APP)-like immunoreactivities. J Comp Neurol 1983a; 217: 252-263.

98. Vincent SR, Staines WA, Fibiger HC. Histochemical demonstration of separate populations of somatostatin and cholinergic neurons in the rat striatum. Neurosci Lett 1983b; 35: 111-114.

99. Difiglia $\mathrm{M}$, Aronin N. Ultrastructural features of immunoreactive somatostatin neurons in the rat caudate nucleus. J Neurosci 1982; 2: 1267-1274

100. Takagi H, Somogyi P, Somogyi J, et al. Fine structural studies on a type of somatostatin-immunoreactive neuron and its synaptic connections in the rat neostriatum: A correlated light and electron microscopic study. J Comp Neurol 1983; 214: 1-16.

101. Vincent SR, Johansson O. Striatal neurons containing both somatostatin-and avian pancreatic polypeptide (APP)-like immunoreactivities and NADPH-diaphorase activity: A light and electron microscopic study. J Comp Neurol 1983; 217:264-270.

102. Takagi $\mathrm{H}$, Mizuta $\mathrm{H}$, Matsuda $\mathrm{T}$, et al. The occurrence of cholecystokinin-like immunoreactive neurons in the rat neostriatum: light and electron microscopic analysis. Brain Res 1984; 309: 346-349.

103. Hökfelt T, Schultzberg M, Lundberg JM, et al. Distribution of vasoactive intestinal polypeptide in the central and peripheral nervous systems as revealed by immunocytochemistry. In: Said SI, ed. Vasoactive Intestinal Ps:ptide. Raven Press, New York, 1982: $65-90$.

104. Skofitsch G, Jacobowitz DM. Immunohistochemical mapping of galanin-like neurons in the rat central nervous system. Peptides 1985; 6: 509-546.

105. Mensah PL. The internal organization of the mouse caudate nucleus: Evidence for cell clustering and regional variation. Brain Res 1977; 137: 53-66.

106. Mensah PL. Distribution of the largest neuron in mouse caudateputamen nucleus: Its position in large-cell-medium-cell clusters. Exp Brain Res 1980; 38: 267-271.

107. Goldman-Rakic PS. Cytoarchitectonic heterogeneity of the primate neostriatum: Subdivision into island and matrix cellular compartments. J Comp Neurol 1982; 205: 398-413.

108. Graybiel AM, Ragsdale CW Jr. Histochemically distinct compartments in the striatum of human, monkey, and cat demonstrated by acetylthiocholinesterase staining. Proc Natl Acad Sci 1978; 75: 5723-5726.

109. Pert CB, Kuhar MJ, Snyder SH. Opiate receptor: Autoradiographic localization in rat brain. Proc Natl Acad Sci 1978; 73: 3729-3733.

110. Herkenham M, Pert CB. Mosaic distribution of opiate receptors, parafascicular projections and acetylcholinesterase in rat striatum. Nature 1981; 291: 415-418.

111. Graybiel AM, Ragsdale CW Jr, Yoneoka ES, et al. An immunohistochemical study of enkephalins and other neuropeptides in the striatum of the cat with evidence that the opiate peptides are arranged to form mosaic patterns in register with the striosomal compartments visible by acetylcholinesterase staining. Neurosci 1981; 6: 377-397.

112. Graybiel AM, Pickel VM, Joh TH, et al. Direct demonstration of a correspondence between the dopamine islands and acetylcholinesterase patches in the developing striatum. Proc Natl Acad Sci 1981; 78: 5871-5875

113. Graybiel AM, Chesselet MF. Compartmental distribution of striatal cell bodies expressing [Met]enkephalin-like immunoreactivity. Proc Natl Acad Sci 1984; 81: 7980-7984.

114. Goedert M, Mantyh PW, Hunt SP, et al. Mosaic distribution of neurotensin-like immunoreactivity in the cat striatum. Brain Res 1983; 274: 176-179

115. Goedert M, Mantyh PW, Emson PC, et al. Inverse relationship between neurotensin receptors and nerotensin-like immunoreactivity in cat striatum. Nature $1984 ; 307: 543-546$.

116. Gerfen CR. The neostriatal mosaic: Compartmentalization of corticostriatal input and striatonigral output systems. Nature 1984; 311: 461-464.

117. Gerfen CR. The neostriatal mosaic. 1. Compartmental organization of projections from the striatum to the substantia nigra in the rat. J Comp Neurol 1985; 236: 454-476.

118. Sandell JH, Graybiel AM, Chesselet MF. A new enzyme marker for striatal compartmentalization: NADPH diaphorase activity in the caudate nucleus and putamen of the cat. J Comp Neurol 1986; 243: 326-334.

119. Graybiel AM. Neurochemically specified subsystems in the basal ganglia, In: Evered D, O'Connor M, eds. Functions of the basal ganglia (Ciba Foundation Symposium 107), Pitman, London, 1984b: 114-149.

120. Graybiel AM, Baughman RW, Eckenstein F. Cholinergic neuropil of the striatum observes striosomal boundaries. Nature 1986; 323: 625-627.

121. Nastuk MA, Graybiel AM. Patterns of muscarinic cholinergic binding in the striatum and their relation to dopamine islands and striosomes. J Comp Neurol 1985; 237: 176-194.

122. Brand $S$. A comparison of the distribution of acetylcholinesterase and muscarinic cholinergic receptors in the feline neostriatum. Neurosci Lett 1980; 17: 113-117.

123. Olson L, Seiger A, Fuxe K. Heterogeneity of striatal and limbic dopamine innervation: Highly fluorescent islands in developing and adult rats. Brain Res 1972; 44: 283-288.

124. Moon Edley S, Herkenham M. Comparative development of striatal opiate receptors and dopamine revealed by autoradiography and histofluorescence. Brain Res 1984; 305: 27-42.

125. Agnati LF, Fuxe K, Anderson K, et al. The mesolimbic dopamine system: Evidence for a high amine turnover and for a heterogeneity of the dopamine neurons population. Neurosci Lett 1980; 18: 45-51.

126. Tennyson VM, Barrett RE, Cohen G, et al. The developing neostriatum of the rabbit: Correlation of fluorescence histochemistry, electron microscopy, endogenous dopamine levels, and $(3 \mathrm{H})$ dopamine uptake. Brain Res 1972; 46: 251-285.

127. Fukui K, Kariyama H, Kashiba A, et al. Further confirmation of heterogeneity of the rat striatum: Different mosaic patterns of dopamine fibers after administration of methamphetamine or reserpine. Brain Res 1986; 382: 81-86.

128. Joyce JN, Douglas WS, Marshall JF. Human striatal dopamine receptors are organized in compartments. Proc Natl Acad Sci 1986; 83: 8002-8006.

129. Künzle J. Bilateral projections from precentral motor cortex to the putamen and other parts of the basal ganglia. Brain Res 1975; 88: $195-210$.

130. Kalil K. Patch-like termination of thalamic fibers in the putamen of the rhesus monkey: An autoradiographic study. Brain Res 1978; 140: 333-339.

131. Donoghue JP, Herkenham M. Neostriatal projections from individual cortical fields conform to histochemically distinct striatal compartments in the rat. Brain Res 1986; 365: 397-403.

132. Ragsdale CW Jr, Graybiel AM. The fronto-striatal projection in the cat and monkey and its relationship to inhomogeneities established by acetylcholinesterase histochemistry. Brain Res 1981; 208: 259-266.

133. Beckstead RM. Complementary mosaic distributions of thalamic and nigral axons in the caudate nucleus of the cat: Double anterograde labeling combined autoradiography and wheat germHRP histochemistry. Brain Res 1985; 335: 135-159.

134. Wright AK, Arbuthnott GW. The pattern of innervation of the corpus striatum by the substantia nigra. Neurosci $1981 ; 6$ : 2063-2067.

135. Herkenham M, Moon Edley S, Stuart J. Cell clusters in the nucleus accumbens of the rat, and the mosaic relationship of opiate receptors, acetylcholinesterase and subcortical afferent terminations. Neurosci 1984; 11: 561-593.

136. Gerfen CR, Baimbridge KG, Thibault J. The neostriatal mosaic. 
III. Biochemical and developmental dissociation of dual patchmatrix nigrostriatal systems. J Neurosci (In press).

137. Graybiel AM, Ragsdale CW Jr, Moon Edley S. Compartments in the striatum of the cat observed by retrograde cell labeling. Exp Brain Res 1979; 34: 189-195.

138. Kent JL, Pert CB, Herkenham M. Ontogeny of opiate receptors in rat forebrain: Visualization by in vitro autoradiography. Dev Brain Res 1982; 2: 487-504.

139. Lança AJ, Boyd S, Kolb B, et al. The development of a patchy organization of the rat striatum. Dev Brain Res 1986; $27: 1-10$.

140. Rotter A, Field PM, Raisman G. Muscarinic receptors in the central nervous system of the rat. 111. Postnatal development of binding of $\left[{ }^{3} \mathrm{H}\right]$ propylbenzilylcholine mustard. Brain Res 1979 ; 180(2): 185-205.

141. Goedert M, Hunt SP, Mantyh PW, et al. The ontogenetic development of neurotension-like immunoreactivity and neurotensin receptors in the cat striatum. Dev Brain Res 1985; 20: 127-131.

142. Butcher LL, Hodge GK. Postnatal development of acetylcholinesterase in the caudate-putamen and substantia nigra of rats. Brain Res 1976; 106: 223-240.

143. Graybiel AM, Ragsdale CW Jr. Clumping of acetylcholinesterase activity in the developing striatum of the human fetus and young infant. Proc Natl Acad Sci 1980; 77: 1214-1218.

144. Graybiel AM. Correspondence between the dopamine islands and striosomes of the mammalian striatum. Neurosci 1984a; 13: 1157-1187.

145. Graybiel AM, Hickey TL. Chemospecificity of ontogenetic units in the striatum: Demonstration by combining $\left[{ }^{3} \mathrm{H}\right]$ thymidine autoradiography and histochemical staining. Proc Natl Acad Sci 1982; 79: 198-202.

146. Van der Kooy D, Fishell G. Neuronal birthdate underlies the development of striatal compartments. Brain Res 1987; 401: 155-161.

147. Marchand R, Lajoie L. Histogenesis of the striopallidal system in the rat. Neurogenesis of its neurons. Neurosci 1986; 17: 573-590.

148. Van der Kooy D. Development relationships between opiate receptors and dopamine in the formation of caudate-putamen patches. Dev Brain Res 1984; 14: 300-303.

149. Hubel DH, Wiesel TN. Receptive fields, binocular interaction and functional architecture in the cat's visual cortex. J Physiol (Lond) 1962; 160: 106-154.

150. Woolsey TA, Van Der Loos $\mathbf{H}$. The structural organisation of layer IV in the somatosensory region (SI) of mouse cerebral cortex. The description of a cortical field composed of discrete cytoarchitectonic units. Brain Res 1970; 17: 205-242.

151. Heimer L, Wilson RD. The subcortical projections of the allocortex: Similarities in the neural associations of the hippocampus, the piriform cortex, and the neocortex. Golgi Cent Symp Proc 1975: 177-193.

152. Penny GR, Wilson CJ, Kitai ST. The influence of neostriatal patch and matrix compartments on the dendritic geometry of spiny projection neurons in the rat as revealed by intracellular labeling with HRP combined with immunocytochemistry. Soc Neurosci Abstr 1984; 10: 514. 